\section{Model for dimensioning the audit structures in the public sector}

Elena Doina DASCĂLU, Spiru Haret University of Bucharest, The Romanian Court of Accounts, E-mail:doina.dascalu@rcc.ro

\section{Alsstract}

This article proposes a solution to determine the size of the internal audit departments in public sector organisations. The conceptual model for determining the actual size of an internal audit department, as adopted by the Institute of Internal Auditors (IIA), is presented and the various factors used in dimensioning are analysed.

The article also presents a computational model for the public sector, illustrated by means of a procedure which is based on the size of the organization and uses specific calculation variables and explicit (clearly defined) correction coefficients to determine the final number of internal auditors.

The variables and the coefficients of the described model cover the significant factors that might influence the size of the internal audit department. At the same time, the requirements of adequacy and usefulness of the model for the various entities of the public sector are insured.

The model proposed for the public sector entities constitutes also a supporting tool for the practical implementation of the legal, regulatory and normative requirements with regard to the sizing of the internal audit departments.

Keywords: Internal audit in the public sector, sizing of the audit departments, critical factors for sizing. calculation model for dimensioning.

JEL Classification: M42; M48

\section{To cite this article:}

Dascălu, E.D. (2016), Model for dimensioning the audit structures in the public sector, Audit Financiar, vol. XIV, no. 8(140)/2016, pp. 909-917,

DOI: 10.20869/AUDITF/2016/140/909

To link to this article:

http://dx.doi.org/10.20869/AUDITF/2016/140/909 


\section{Introduction}

In keeping with the provisions of art. 11 letter a) of Law no. $672 / 2002$ on internal public audit, reissued, as subsequently modified and completed, the head of the public institution or, in the instance of other public entities, the collective management body, is under the obligation to ensure the organisation and operation framework required for the conduct of the internal audit activity.

Furthermore, the mentioned normative act provides, under art. 2 letter $\mathrm{f}$ ) that the name of internal public audit department is generic, while the organization structure of internal public audit is established in relation to the activities complexity and volume, as well as with the risks associated to the respective public entity.

Thus, the above-mentioned normative act established the requirement of sizing a generically called internal public audit department, a sizing which would ground the setting of the organization of internal audit in the public entity, respectively general directorate, directorate, service, office or department. Irrespective of the sizing result, the normative provision establishes that the number of auditors in a public entity should be at least two (full-time staff).

Relating to sizing, the General norms on the conduct of internal public audit activity approved based on Government Decision no. 1086/2013 provide the requirement that the following stages should be covered:

a. Identification of all activities conducted both within the public entity, and within the entities subordinated/ coordinated/under the latter's authority, in which the former conducts directly internal public audit missions;

b. Identification of risks associated to activities;

c. Identification of internal control forms attached to each activity;

d. Setting residual risks following conduct of control forms;

e. Setting the time required to conduct internal public audit missions, by considering the following factors: budget allotted to the entity; number of entities subordinated/ coordinated/ under its authority; number of employees; specific character of the public entity; complexity and social importance of the activities; observance of periodicity in auditing; activities involving high/medium risks.
The above-mentioned stages are based on the subjectivity of the person conducting the sizing process, since they provide identification of risks associated to all activities unfold at the level of the public entity, of the control forms established for their management, as well as of residual risks, without building a direct connection between residual risk and the time required to conduct audit missions.

That is the reason why the implementation of the abovementioned stages by two different persons may lead to significant differences among the results obtained, generated by the number of identified risks, by the assessment of residual risks and the time required to conduct internal public audit missions in a given entity.

Even if, as mentioned before, Law no. 672/2002 provides the mandatory character of internal audit department sizing at the charge of the public institution head, the latter does not have a model available, adapted to the specific character of the public sector in Romania, so as to fulfil this obligation.

The Report on internal audit activity in the public sector for 2013 shows that about $73 \%$ of internal audit departments have a single internal auditor position, which shows that the sizing process did not consider covering the stages or implementing the criteria provided in the General norms on the conduct of internal public audit activity, approved by Government Decision no. 1086/2013.

The possible causes of the failure to enforce the stages provided in the General norms on the conduct of internal public audit activity to size internal audit departments in the public sector may be the following:

- Difficulties in the implementation of the stages provided by law, especially concerning the identification of residual risks;

- Absence of a model/a methodology to quantify the number of auditor positions in relation to the abovementioned factors;

- Absence of contravention fines or of other penalties provisions in the Law no. 672/2002 on internal public audit for setting the number of positions;

- Absence of a system assessment regarding the internal public audit situation in Romania, especially with respect to sizing;

- Risk management is insufficiently developed in the public sector in Romania. 


\section{Literature review}

De Koning (2007) considers - relating to the organisation of internal audit at the level of a public entity - that the responsibility to set up the internal audit department lays with its manager. This responsibility also includes the adequate sizing of the internal audit structure, for it to have the capacity to cover the scope of the activities unfold in the public entity.

Furthermore, an adequate sizing involves answering the question: What percent of the resources of an organisation should be allotted to the internal audit function? (Anderson et al., 2010a).

In keeping with the study on the internal audit activity conducted by Ernst \&Young (2013) at global level, in 2013 , over $30 \%$ of respondents (internal audit executive managers) mentioned an increase of the audit function in the previous year, while $37 \%$ expected an increase in the subsequent 24 months.

With respect to the sizing, the General norms on the conduct of internal public audit activity, approved based on Government Decision no. 1086/2013, stipulate the necessity of completing well-defined stages and the application of well-defined criteria relating to the sizing of internal audit structures.

\section{Research methodology}

Given the importance of achieving an appropriate sizing of the number of auditors (i.e., department sizing) in public entities, it is important to consider the issue of setting up a model for internal audit department sizing in public entities, in order to perform an adequate sizing of internal audit number in the public sector.

The research methodology was based on the study of the specialised literature relating to determinants and models used for internal audit department sizing (Renard, 2004; Spencer Pickett, 2006 a,b; Bal, 2012). In addition, existing analyses on the issue have been studied as well, in order to establish a model for the setting of the number of internal auditors in public entities.

Starting from the specifics of the public sector in Romania, the research methodology aimed at establishing a formula to generate the number of internal auditors, by extrapolating or adjusting the factors resulting from the literature on sizing internal audit departments.

\section{The sizing of audit departments in public entities}

The approach on establishing a model for audit departments sizing in public entities is based on the Model on internal audit department sizing, established by (Anderson et al., 2010), which set the optimal size of an internal audit department based on the consideration of seven factors, critical for the internal audit activity.

\subsection{Drivers for sizing}

Adopting as a condition the establishment of the sizing model based on the critical factors, we herein propose for the sizing of internal audit departments in the public sector - the following set of determinants:

a. Organisation size (number of employees in the organisation);

b. The budget of the public entity;

C. The patrimony (assets) of the entity;

d. The complexity of the activities included in the sphere of internal audit;

e. The experience of auditing staff;

f. The risk level of the entity;

g. The auditing periodicity;

h. The localisation.

Next, we present a short description of the influence and effects of each of these factors.

a. The organisation size: the factor involving the organisation size, respectively the number of employees in the entity, aims at establishing a correlation between the number of internal auditors and the number of employees of an organisation. Thus, the starting point of internal audit departments sizing is the number of employees in the institution, a higher number of employees involving an increase in the internal audit department size.

b. The budget of the public entity represents a factor influencing the impact of the risks associated to the activities conducted by the public entity. In this respect, the increase of an entity budget triggers a 
high level of risks associated to the activities being the object of internal audit (by influencing the impact), a reason why it is necessary to allot a larger volume of time for the audit, since the domains displaying risks are audited, as a general rule, on a yearly basis. Consequently, the larger the budget of an organisation as compared to a certain threshold, the higher the number of auditors needs to be, so as to allow for the yearly auditing of risky domains.

c. The same reasoning applies in the instance of the entity patrimony (assets), since exceeding a certain threshold triggers the increase of the number of auditors, so as to conduct audit of risky domains on a yearly basis.

d. The factor involving activities complexity covered by the scope of internal audit envisages that the duration of a mission depends on the difficulty and number of operations to be audited. That is why a higher complexity supposes a larger time volume allotted to audit missions, which may be attained by increasing the number of internal auditors.

e. The auditing staff experience is a factor involving the human resources used in the audit. The duration of the internal audit missions is influenced by the competence of internal auditors, which in turn depends on experience, international certification in the field, stability, employment criteria etc.

f. The risk level of the entity refers to a global assessment of the risk associated to a certain organisation, a higher risk level requiring more frequent audit missions, respectively a larger time volume and, implicitly, a higher number of auditors. This is true, for instance, in the case of two public entities which are similar in size, but have different risk assessments.

g. Auditing periodicity involves compliance with legal requirements, respectively auditing at least 10 systems/domains at least once every three years, as well as setting a time interval to audit most of the activities unfolding in an organisation, irrespective of risk level.

h. The localisation factor refers to the increase the number of auditors when the audited entities are located at large distances, in order to consider the travel issues.

\subsection{Sizing model and example of its implementation}

Based on the determinants listed above, a model may be established to size internal audit departments in the public sector, starting from the following conditions and variables:

- Compliance with auditing periodicity, respectively auditing, at least once every three years, the mandatory domains and systems provided under art. 15 of Law no. 672/2002 (10 domains and systems);

- Ensuring a five-year auditing periodicity, so that the organisation domains of activity be audited at least once every five years (variable $V_{1}$ );

- Including all activities unfolding by a public entity in the internal audit sphere;

- The time volume allotted to counselling activities would represent $10 \%$ of the overall time (variable $\mathrm{V}_{2}$ );

- For ad-hoc audit missions, $5 \%$ of the overall time would be allotted (variable $\mathrm{V}_{3}$ );

- The average duration of an assurance audit mission is 160 man-days, respectively 40 working days $\times 4$ auditors (variable $\mathrm{V}_{4}$ );

- A person may conduct audit missions in maximum four activity domains, in a five-year period, that is an auditor may only conduct audit missions in maximum four domains (variable $V_{5}$ );

- The available time for a person to conduct internal audit is an average of 170 days (variable $V_{6}$ ).

\subsubsection{The proposed sizing model}

Sizing internal audit departments in the public sector involves - in keeping with the model we propose covering seven steps, to set the number of internal auditors.

STEP 1. Preliminary setting of the internal auditors number based on the organisation staff number, thus obtaining the minimum number of internal auditors $\left(\mathrm{N}_{1}\right)$.

A matrix can be used to set the minimum number of internal auditors; the first column would represent the number of employees (incremental), and the first line the number of employees for one 
internal auditor (incremental). At the intersection of the line with the column, there would result the number of internal auditors, by dividing the number of employees to the number of employees for one internal auditor and rounding it by adding up (See Table 1 below).

\begin{tabular}{|c|c|c|c|c|c|c|c|c|c|c|c|}
\hline \multicolumn{12}{|c|}{ Number of employees for one auditor } \\
\hline & 30 & 50 & 70 & 100 & 150 & 200 & 250 & 300 & 350 & 400 & 450 \\
\hline 100 & 3 & 2 & 1 & 1 & 1 & 1 & 0 & 0 & 0 & 0 & 0 \\
\hline 200 & 7 & 4 & 3 & 2 & 1 & 1 & 1 & 1 & 1 & 1 & 0 \\
\hline 500 & 17 & 10 & 7 & 5 & 3 & 3 & 2 & 2 & 1 & 1 & 1 \\
\hline 1,000 & 33 & 20 & 14 & 10 & 7 & 5 & 4 & 3 & 3 & 3 & 2 \\
\hline 5,000 & 167 & 100 & 71 & 50 & 33 & 25 & 20 & 17 & 14 & 13 & 11 \\
\hline 10,000 & 333 & 200 & 143 & 100 & 67 & 50 & 40 & 33 & 29 & 25 & 22 \\
\hline 30,000 & 1,000 & 600 & 429 & 300 & 200 & 150 & 120 & 100 & 86 & 75 & 67 \\
\hline 50,000 & 1,667 & 1,000 & 714 & 500 & 333 & 250 & 200 & 167 & 143 & 125 & 111 \\
\hline 100,000 & 3,333 & 2,000 & 1,429 & 1,000 & 667 & 500 & 400 & 333 & 286 & 250 & 222 \\
\hline
\end{tabular}

Source: Author's compilation, 2016

Based on this matrix, intervals depending on the number of employees of the public entity are established, indicating the minimum and maximum number of internal auditors. From the interval, an initial number of internal auditors is selected, an example being presented in Table 2.

\section{Table 2. Selection of the initial number of internal auditors}

\begin{tabular}{|l|l|c|}
\hline Item no. & \multicolumn{1}{|c|}{ Number of employees in the public entity } & $\begin{array}{c}\text { Interval from which the minimum internal auditors } \\
\text { number is established [minimum - maximum] }\end{array}$ \\
\hline 1. & Less than 100 & {$[2-3]$} \\
\hline 2. & Between 100 and 199 & {$[3-4]$} \\
\hline 3. & Between 200 and 499 & {$[4-7]$} \\
\hline 4. & Between 500 and 999 & {$[5-10]$} \\
\hline 5. & Between 1,000 and 4,999 & {$[7-20]$} \\
\hline 6. & Between 5,000 and 9,999 & {$[15-40]$} \\
\hline 7. & Between 10,000 and 29,999 & {$[25-70]$} \\
\hline 8. & Between 30,000 and 49,999 & {$[50-120]$} \\
\hline 9. & Between 50,000 and 99,000 & {$[100-250]$} \\
\hline 10. & More than 100,000 & {$[$ More than 250] } \\
\hline
\end{tabular}

Source: Author's compilation, 2016

STEP 2. Setting the required time volume (FdTnec) to conduct internal audit of all the activities unfold by the public entity, considering the conditions mentioned, as well as variables $V_{1}, V_{2}, V_{3}, V_{4}$ and $V_{5}$.

STEP 3 . Setting the time volume available for internal audit (FdTdisp), by multiplying the number of auditors chosen as an (estimated) value to start the calculation procedure with the time available to a person for internal audit, using the formula: FdTdisp $=\mathrm{N}_{1} \times \mathrm{V}_{6}$.

STEP 4. A comparison is made of the time available for internal audit (FdTdisp) with the required time (FdTnec). In case FdTdisp<FdTnec increases $\mathrm{N}_{1}$ until coverage of the necessary time (volume of activity), resulting the new number 
of internal auditors $\left(\mathrm{N}_{2}\right)$. If FdTdisp $>$ FdTnec $\mathrm{N}_{1}$ may be subtracted or adjusted in the following steps.
STEP 5. The number of auditors $\left(\mathrm{N}_{2}\right)$ is adjusted with the correction coefficients, individually or cumulatively, thus obtaining the final number of auditors $\left(N_{f}\right)$, as follows:

$$
N_{f}=N_{2}+N_{2} x k_{B} \pm N_{2} x k_{R}+N_{2} x k_{p} \pm N_{2} x k_{c} \pm N_{2} x k_{e}+N_{2} x k_{1}
$$

where:

a. The budget coefficient $\left(k_{B}\right)$ involves increasing the number of auditors in case the annual budget allotted to the entity in relation to the number of auditors $\left(\mathrm{N}_{2}\right)$ exceeds the threshold $\mathrm{P}_{\mathrm{B}}$ (for example, $35,000,000$ lei). In this instance, the number of auditors is increased by the budget coefficient (for example, $\mathrm{k}_{\mathrm{B}}=10 \%$ );

b. The risk coefficient $\left(k_{R}\right)$ involves supplementing the number of auditors or diminishing it, according to the case, in relation to risk (for example, $\mathrm{k}_{\mathrm{R}}= \pm 10 \%$ ). To quantify the risk level, three stages may be used, respectively: small risk (the number of auditors is diminished), average risk (the number of auditors is maintained in keeping with the assessment), high risk (the number of auditors is supplemented). Risk level may be established in relation to a series of risk factors, such as: management quality, penalties and fraud/corruption instances, previous significant errors, staff fluctuation, results of controls by the Court of Accounts or by other bodies etc.

c. The patrimony coefficient $\left(k_{P}\right)$ involves increasing the number of auditors in case the annual patrimony being managed by the entity exceeds a certain threshold, marked $P_{p}$. In this instance, the number of auditors is supplemented by the patrimony coefficient (for example, $\mathrm{k}_{\mathrm{P}}=10 \%$ );

d. The complexity coefficient $\left(k_{c}\right)$ involves increasing the number of auditors in the instance of highly complex activities. Among complex activities are those conducted by main authorising officers, as well as other defined activities (for example, the ones of a nuclear plant). Furthermore, in the instance of activities considered to have a low complexity, the coefficient may trigger the decrease of the number of auditors. Consequently, the complexity coefficient may take values involving the increase or decrease of the number of auditors (for example, $\mathrm{k}_{\mathrm{c}}= \pm 10 \%$ );

e. Auditing experience coefficient $\left(k_{e}\right)$ involves increasing the number of auditors in the instance of auditors lacking experience, not using information systems-based audit techniques, or the decreasing the number of auditors in the instance of internationally chartered auditors, having an experience of over three years in the field or who use information systems-based audit techniques (for example, $\mathrm{k}_{\mathrm{c}}= \pm 10 \%$ );

f. The location coefficient $\left(k_{1}\right)$ involves increasing the number of auditors in the instance of auditees located in different places, at distances of over 50 $\mathrm{km}$ (for example, $\mathrm{k}_{\mathrm{l}}=5 \%$ ).

In the end, based on the final number of internal auditors thus set, it is possible to establish the organisation structure of internal audit in the respective organisation.

The model proposed for the sizing of internal audit departments in the public sector is based on the conceptual model drafted by Anderson et al. (2010), on the factors required to set the number of auditors mentioned in the specialised literature, on the requirements of the national normative framework in the field, as well as on the specific characteristics of the public sector in Romania.

This model grants compliance with the provisions of Law no. 672/2002 and of the General norms on the conduct of internal public audit activity, approved based on Government Decision no. 1086/2013, in the sense that the number of auditors is established in relation to the volume of activity and size of associated risks, the last element being quantified based on risk factors/ coefficients (for example, fraud risk, error risk etc.).

Testing and putting into practice this model in the public sector would minimise the under-sizing risk and subjectivism in setting a number of auditors by grounding it, respectively documenting it based on professional judgement.

\subsubsection{Example of implementing the model for sizing audit compartments in the public sector}

The following data on a public sector organisation is considered for exemplification: 
- Total number of employees: 35,000;

- 4 subordinated or coordinated entities;

- Total budget of the entity (including subordinated or coordinated entities): 10 billion lei.

To continue, the Model proposed for the sizing of audit departments in the public sector is implemented, covering the previously mentioned steps.

\section{STEP 1. Setting the minimum number of internal} auditors. Given that the total number of employees in the entity is 35,000 , we set the minimum number of internal auditors $\left(\mathrm{N}_{1}\right)$ based on the table of correspondence (Table 1), between the number of employees and the corresponding interval (line no. 8).

Given that 35,000 is closer to the lower limit of the interval $(30,000)$, we choose the minimum number of internal auditors as being $60\left(\mathrm{~N}_{1}=60\right)$.
STEP 2. Setting the time volume required (FdTnec) to perform the internal audit of all the activities conducted by the public entity. In this instance, we consider that the conditions and values awarded to variables $V_{1}, V_{2}, V_{3}, V_{4}$ and $V_{5}$ are true. To do that, we identify (issues resulting from the multi-annual internal audit plan drafting) the number of public entities where audit is going to be conducted (five entities), respectively the main one, and the four subordinated or coordinated entities.

In keeping with the legislation in the field of internal public audit, auditing periodicity needs to be observed, respectively, at least once every three years, 10 domains or systems need to be audited. That is why, the time required (a first component part) shall be calculated as follows:

$$
\mathrm{FdTnec}_{1}=5^{\text {entities }} \times 10 \text { mandatory domains and systems } \times 160 \text { duration of one mission (man-days) } / 3 \text { years }=2.667 \text { man-days }
$$

The conditions set provide that it is mandatory to audit all auditable domains, at least once every five years. If we assume that 50 more domains and systems were identified (which add to the 10 ones which are mandatory by law), applying a similar formula it is possible to identify the necessary time volume FdTnec 2 . Consequently, the second component of the time required is calculated as follows:

$$
\mathrm{FdTnec}_{2}=5^{\text {entities }} \times 50 \text { domains and systems } \times 160 \text { duration of one mission (man-days) } / 5^{\text {years }}=8.000 \text { man-days }
$$

If ad-hoc missions are allotted $5 \%$ of the overall time volume, and the time allotted to counselling activities represents $10 \%$ of the overall time, the following result is obtained:

$$
\text { FdTnec }\left(\text { FdTnec }_{1}+\text { FdTnec }_{2}\right) \times 1,05 \times 1,1=(2.667+8.000) \times 1,05 \times 1,1=12.320 \text { man-days }
$$

STEP 3. Establishing the time volume available for internal audit (FdTdisp). The time volume is calculated by multiplying the number of auditors selected as an (estimated) starting value for the calculation procedure, with the time volume available to one person for internal audit, according to the formula:

$$
\text { FdTdisp }=N_{1} \times V_{6}=60 \text { auditors } \times 170 \text { time available for audit }=10.200 \text { man-days }
$$

\section{STEP 4. Making a comparison between the time available for internal audit (FdTdisp) and the time required ( $\mathrm{FdTnec}$ ).}

In the above example, FdTdisp $=10,200$ mandays $<$ FdTnec $=12,320$ man-days (see formulas (4) and (5)): in this instance, $N_{1}$ is increased until the required time volume is covered (the activity volume), and there results a new number of internal auditors $\left(\mathrm{N}_{2}\right)$, according to the following relation:

$$
\mathrm{N}_{2}=\mathrm{FdTnec} / 170 \text { the time available for audit }=12.320 \text { man-days } / 170=73 \text { internal auditors }
$$


STEP 5. Adjusting the number of auditors $\left(\mathrm{N}_{2}\right)$. The updated auditors number, $\mathrm{N}_{2}$ is adjusted with the correction coefficients, individually or cumulatively, thus resulting the final number of auditors $\left(N_{f}\right)$.

a. The budget coefficient $\left(k_{B}\right)$. We establish the threshold:

$\mathrm{P}_{\mathrm{B}}=$ Budget $/ \mathrm{N}_{2}=10,000,000,000 / 73 \approx 137,000,000>$ $35,000,000$ lei.

In this instance, a budget coefficient of $10 \%$ $\left(k_{B}=10 \%\right)$ is set.

b. The risk coefficient $\left(k_{R}\right)$. Three steps are used to quantify the risk level, respectively: small risk (1), medium risk (2) and high risk (3), according to Table 3. Considering that risk was assessed as being low (see Table 3), the coefficient applied is $k_{R}=-10 \%$. c. The patrimony coefficient $\left(k_{P}\right)$. It is considered that the patrimony administered does not exceed the set threshold $\left(P_{P}\right)$. In this instance, the coefficient is 0 $\left(\mathrm{k}_{\mathrm{P}}=0 \%\right)$;

d. The complexity coefficient $\left(k_{c}\right)$. The activities are considered to have a high complexity, in this instance the complexity coefficient being $\mathrm{k}_{\mathrm{c}}=10 \%$;

e. The auditing experience coefficient $\left(k_{e}\right)$. It is considered that the average seniority of auditors is three years, they are also chartered. In this instance, the experience coefficient is $0\left(k_{c}=0 \%\right)$;

$f$. The location coefficient $(k)$. All entities being in Bucharest, the location coefficient is $0\left(\mathrm{k}_{\mathrm{l}}=0 \%\right)$;

Based on the coefficients established, the number of auditors $\left(\mathrm{N}_{2}\right)$ is adjusted, and the final number of auditors $\left(N_{f}\right)$ is obtained, as follows:

$$
N_{f}=N_{2}+N_{2} x k_{B} \pm N_{2} x k_{R}+N_{2} x k_{p} \pm N_{2} x k_{c} \pm N_{2} x k_{e}+N_{2} x k_{l}
$$

By replacing the values, we obtain:

$$
N_{f}=73+73 \times 0,1-73 \times 0,1+73 \times 0+73 \times 0,1+73 \times 0=80 \text { internal auditors }
$$

Thus, the final number of internal auditors is 80 , which grounds the

setting of the internal audit department organisation structure.

\begin{tabular}{|c|c|c|c|}
\hline $\begin{array}{l}\text { Item } \\
\text { no. }\end{array}$ & Risk factor & Assessment & Risk level \\
\hline 1. & Management quality & $\begin{array}{l}\text { Management positions are organised based on competitive } \\
\text { examination, by an independent commission. Managers have skills } \\
\text { in the specific field of activity. } \\
\text { Managerial performances are assessed on a yearly basis. }\end{array}$ & Low risk (1) \\
\hline 2. & $\begin{array}{l}\text { Penalties and } \\
\text { fraud/corruption instances }\end{array}$ & $\begin{array}{l}\text { No contravention fines/penalties or corruption/fraud instances were } \\
\text { noted. }\end{array}$ & Low risk (1) \\
\hline 3. & Previous significant errors & No significant errors were noted & Low risk (1) \\
\hline 4. & Staff fluctuation & Under $5 \%$ & Low risk (1) \\
\hline 5. & $\begin{array}{l}\text { Results of audits or controls } \\
\text { performed by the Court of } \\
\text { Accounts or by other bodies }\end{array}$ & No material malfunctions were found following audit missions & Low risk (1) \\
\hline \multicolumn{3}{|r|}{ Average score = 1} & Low risk (1) \\
\hline
\end{tabular}

\section{Table 3. Quantifying the risk level}

Source: Author's compilation, 2016 


\section{Conclusions}

Based on the conceptual model drafted by Anderson et al. (2010) and adopted by IIA, the paper proposes a model for sizing audit compartments in the public sector.

The proposed sizing model can be used in the public sector in Romania whereas it takes account of the specifics of the activities provided by public entities. Thus, the model takes into consideration the organisation's size and is based on variables and correction coefficients, which ensures the necessary adaptation parameters for its application in various fields of activity in the public sector.

The opportunity of the full use of the model for sizing audit departments in the Romanian public sector was exemplified on a hypothetical organization, the model finally providing the optimal number of internal auditors for organizing the internal audit department.
We consider that the use of the model can give rise to two important effects:

a. It will ensure compliance with national legislation in the field of internal audit, on the one hand; and

b. It will ensure a justification as close to the reality as possible of the number of internal auditors, on the basis of mathematical calculations, on the other hand. Thus, there can be avoided the empirical findings and assessments or those which take account only of the resources provided through the budget for similar activities in the past.

Finally, widespread application of the model proposed for the sizing of internal audit departments in the public sector will support increasing the independence and effectiveness of the internal audit, through adequate justification and substantiation of the number of auditors.

\section{REFERENCES}

1. Anderson, U.L., Christ, M.H., Johnstone, K.M. and Rittenberg, L. (2010a), Effective Sizing of Internal Audit Departments, Altamonte Springs: The IIA Research Foundation.

2. Anderson, U.L., Christ, M.H., Johnstone, K.M. and Rittenberg, L. (2010b), Effective Sizing of Internal Audit Activities for Colleges and Universities, Altamonte Springs:The IIA Research Foundation.

3. Bal, S. (2012), How much internal audit is enough?, [pdf] Available at: http://auditandrisk.org. uk/features/how-much-internal-audit-is-enough-, [Accessed May 29, 2016].

4. de Koning, R. (2007), Controlul financiar public intern, www.pifc.eu.

5. Ernst \&Young (2013), Matching Internal Audit talent to organizational business needs - Key findings from the Global Internal Audit Survey, [online] Available at: http://www.ey.com/GL/en/Services/Advisory/MIAtalent-to-business-needs---Key-findings-from-theGlobal-Internal-Audit-Survey-2013 [Accessed May 29, 2016].

6. Hotărârea Guvernului nr. 1086/2013 pentru aprobarea Normelor generale privind exercitarea activitătii de audit public intern.
7. IIA (2009), Internal Audit Capability Model (IA-CM) for the public sector, Available at: https://na.theila.org/iiarf/Public\%20Documents/Inter nal\%20Audit\%20Capability\%20Model\%20|ACM\%20for\%20the\%20Public\%20Sector\%200vervi ew.pdf [Accessed May 29, 2016].

8. IIA (2013), Standardele Internationale pentru Practica Profesională a Auditului Intern (2013), Altamonte Springs: The IIA Research Foundation.

9. Legea $n r .672 / 19.12 .2002$ privind auditul public intern, republicată (M.O. nr. 856/ 05.12.2011), cu modificările ulterioare.

10. Ministerul Finanțelor Publice (2013), Raport privind activitatea de audit intern din sectorul public pe anul 2013, [pdf] Available at: http://discutii. mfinante.ro/static/10/Mfp/audit/Rapactivitauditintern 2013_20ian2015.pdf [Accessed May 29, 2016].

11. Renard, J. (2004), Teoria and practica auditului intern, Bucureşti: Editura Arta Grafică.

12. Spencer Pickett, K.H. (2006a), Audit planning - A Risk-Based Approach, New Jersey: John Wiley \& Sons.

13. Spencer Pickett, K.H. (2006b), The Internal Auditing Handbook, New Jersey: John Wiley \& Sons. 